\title{
Margaritaella gracilis gen. n. et sp.n. (Eucestoda: Proteocephalidea), a parasite of Callichthys callichthys (Pisces: Siluriformes) from the Paraná River basin, Argentina
}

\author{
Nathalia J. Arredondo and Alicia A. Gil de Pertierra
}

Laboratorio de Helmintología, Departamento de Biodiversidad y Biología Experimental, Facultad de Ciencias Exactas y Naturales, Ciudad Universitaria, Int. Güiraldes 2160, Pabellón II, 4 Piso, Universidad de Buenos Aires, C1428EGA - Buenos Aires, Argentina

\begin{abstract}
Margaritaella gracilis gen. n. et sp. n. (Proteocephalidea: Proteocephalinae) found in the intestine of Callichthys callichthys (Linnaeus) from the Paraná River basin is described. The new genus is placed in the Proteocephalinae because of the medullary position of the genital organs. It differs from all known genera included in the Proteocephalinae by the following combination of characters: 1) scolex with a conspicuous cluster of drop-shaped gland cells posterior to suckers; 2) strobila with a low number of proglottides, all much longer than wide; 3 ) testes arranged in one field, composed of two parallel rows of testes separated by the uterus; 4) ovary delicate, $\mathrm{H}$-shaped, with branches slender and deeply folliculate at the edges, located at $25-35 \%$ from the posterior end; 5) uterus largely extended posterior to the ovary but not reaching the end of proglottis; and 6) vitelline follicles in two narrow lateral bands, largely extended posterior to the ovary. Scanning electron microscopy revealed three types of microtriches on the tegument surface: acicular and capiliform filitriches and gladiate spinitriches. The relative size of the ovary, a character recently used in the systematics of the proteocephalidean cestodes, was calculated for the new species and compared with other species of the group. M. gracilis is the first record of a proteocephalidean cestode parasitizing a callichthyid catfish.
\end{abstract}

Keywords: Proteocephalinae, taxonomy, morphology, catfish, Callichthyidae, Neotropical region

Cestodes of the order Proteocephalidea Mola, 1928 are widely distributed in the Neotropical region. They are mainly parasites of siluriform fishes inhabiting the great river basins of South America (de Chambrier and Vaucher 1999, Rego et al. 1999, de Chambrier et al. 2006a).

During a survey of the parasite fauna from freshwater fishes of the Paraná River basin (Entre Rios Province, Argentina), Margarita Ostrowski de Núñez (Universidad de Buenos Aires) found specimens of an undescribed proteocephalidean species in the intestine of the catfish Callichthys callichthys (Linnaeus). These tapeworms, described herein, were assigned to the Proteocephalinae La Rue, 1911, but they could not be allocated to any of the known genera. A new genus is proposed to accommodate this new species.

\section{MATERIALS AND METHODS}

Two specimens of Callichthys callichthys (Siluriformes: Callichthyidae) were caught in the Paraná-Guazú River (Paraná

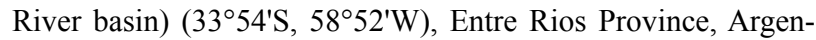
tina, during December 2008 and January 2009. All worms found in the intestines were removed, fixed in hot $4 \%$ formaldehyde solution and subsequently stored in $70 \%$ ethanol. Entire tape- worms were stained with Langeron's alcoholic chlorhydric carmine (Langeron 1949), differentiated in acid ethanol, dehydrated through a graded ethanol series, cleared in beechwood creosote and mounted in Canada balsam. Details of the internal anatomy were determined from thick, hand-cut, transverse serial sections of proglottides stained with Langeron's alcoholic chlorhydric carmine.

Two specimens of the new species were prepared for scanning electron microscopy (SEM) as follows: worms were postfixed in $1 \%$ osmium tetroxide, dried with hexamethyldisilazane (Riedel-De Haën ${ }^{\circledR}$ ), mounted on stubs with adhesive tape, sputter coated with gold in a Thermo VG Scientific Polaron SC 7630 and examined with a Philips XL 30 scanning electron microscope. The types and distribution of microtriches were studied on the scolex, proliferation zone and proglottides of the specimens. Measurements of the microtriches were made from photomicrographs. Terminology used for describing the microtriches follows Chervy (2009).

Unless otherwise stated, all measurements are given in micrometres. Measurements include the range followed by the mean in parentheses, standard deviation, the coefficient of variability (CV) and number of observations (n). For two-dimensional measurements, length is given before width. The relative size of the ovary was calculated according to de Chambrier et al. (2012). Illustrations were made with the aid of a camera lu-

Address for correspondence: N.J. Arredondo, Laboratorio de Helmintología, Departamento de Biodiversidad y Biología Experimental, Facultad de Ciencias Exactas y Naturales, Ciudad Universitaria, Int. Güiraldes 2160, Pabellón II, $4^{\circ}$ Piso, C1428EGA - Buenos Aires, Universidad de Buenos Aires, Argentina. Phone: ++54 11 4576-3349; Fax: ++54 11 4576-3384; E-mail: arredondonj@bg.fcen.uba.ar 
cida attached to a Zeiss Axioscope microscope equipped with differential interference contrast optics. Fish classification and authorities follow FishBase (Froese and Pauly 2012).

Holotype and paratypes were deposited in the Parasitological Collection of the Museo Argentino de Ciencias Naturales "Bernardino Rivadavia", Buenos Aires, Argentina (MACN-Pa) and in the Institute of Parasitology, České Budějovice, Czech Republic (IPCAS)

\section{RESULTS}

\section{Margaritaella gen. $\mathrm{n}$.}

Proteocephalidea, Proteocephalidae, Proteocephalinae. Testes, ovary, vitelline follicles, and uterus medullary. Small-sized worms, flattened dorsoventrally. Strobila acraspedote, with all proglottides much longer than wide. Scolex with conspicuous cluster of drop-shaped gland cells posterior to suckers, not surrounded by membrane and without retractor muscle bundles. Suckers uniloculate, almost spherical. Metascolex absent. Testes distributed in one layer, arranged in one field composed of two parallel rows separated by preformed uterus. Genital pore irregularly alternating, almost equatorial. Ovary delicate, $\mathrm{H}$-shaped, with branches slender and deeply folliculate at edges, located at one-third from posterior end. Vagina anterior or posterior to cirrus-sac, without vaginal sphincter. Vitelline follicles scarce, arranged in two lateral bands, with few follicles paramuscular, largely extending posterior to ovary, not reaching end of mature and gravid proglottides. Uterine development of type 1 (sensu de Chambrier et al. 2004), uterus preformed, extending largely posterior to ovary in mature and gravid proglottides, not reaching end of proglottis. Parasites of Callichthyidae. Type and only species: Margaritaella gracilis sp. n.

Etymology: The generic name is given in honour of Dr.

Margarita C. Ostrowski de Núñez, who generously donated material for this study and greatly contributed to the knowledge of trematodes (Digenea); the name should be treated as feminine.

Differential diagnosis. The new genus is placed in the Proteocephalinae by the medullary position of testes, ovary, vitelline follicles and uterus (Schmidt 1986, Rego 1994). The subfamily currently includes 15 genera parasitizing fish, amphibians and reptiles, namely, Barsonella de Chambrier, Scholz, Beletew et Mariaux, 2009; Brayela Rego, 1984; Cairaella Coquille et de Chambrier, 2008; Cangatiella Pavanelli et Machado dos Santos, 1991; Crepidobothrium Monticelli, 1900; Deblocktaenia Odening, 1963; Euzetiella de Chambrier, Rego et Vaucher, 1999; Glanitaenia de Chambrier, Zehnder, Vaucher et Mariaux, 2004; Macrobothriotaenia Freze, 1965; Ophiotaenia La Rue, 1911; Proteocephalus Weinland, 1858, Pseudocrepidobothrium Rego et Ivanov, 2001; Tejidotaenia Freze, 1965; Thaumasioscolex Cañeda-Guzmán, de Chambrier et Scholz, 2001; and Scholzia de Chambrier, Rego et Gil de Pertierra, 2005.
The new genus differs from all the genera mentioned above by combination of the following characters: 1) scolex with a conspicuous cluster of drop-shaped gland cells posterior to suckers; 2) all proglottides much longer than wide; 3) testes arranged almost in one field, formed by two parallel rows of testes separated by the uterus; 4) ovary delicate, H-shaped, with branches slender and deeply folliculate at the edges, situated at one-third from the posterior margin of the proglottis; 5) uterus largely extending posterior to the ovary; and 6) vitelline follicles in two narrow lateral bands, largely extending posterior to the ovary.

\section{Margaritaella gracilis $\mathrm{sp} . \mathrm{n}$.}

Figs. 1-3

Description (based on 12 specimens and pieces of strobila as transverse sections. Measurements made on 4 complete and 2 incomplete worms): Proteocephalidae, Proteocephalinae. Small to medium-sized worms 26$29 \mathrm{~mm}(28)(\mathrm{n}=4)$ in total length. Strobila acraspedote, flattened dorsoventrally, with a low number of proglottides, 28-31 (29) $(\mathrm{n}=4)$, which are much longer than wide, 21-26 (23) $(\mathrm{n}=4)$ immature proglottides (up to appearance of spermatozoa in vas deferens), 2-4 (3) $(n=4)$ mature proglottides (up to appearance of eggs in uterus), and 3-5 $(4)(n=4)$ gravid proglottides. Immature proglottides $150-1720(600 \pm 390, \mathrm{CV}=65 \%) \times 100-310(190$ $\pm 50, \mathrm{CV}=25 \%)(\mathrm{n}=42)$; length/width ratio $1-9: 1$; mature proglottides 1740-2220 (2060) × 190-425 (255) $(\mathrm{n}=9)$; length/width ratio 5-11:1; gravid proglottides 1520-2740 (2280) × 180-320 (260) $(\mathrm{n}=12)$, length/ width ratio 7-12: 1 (Fig. 2A).

Scolex small, quadrangular, formed by four lobes separated by grooves, without metascolex, slightly wider than proliferation zone, 75-105 (90) $(\mathrm{n}=6)$ wide (Fig. 3AC), with conspicuous, deeply embedded cluster of dropshaped gland cells posterior to suckers, not surrounded by membrane and without retractor muscle bundles, 85-125 $(105) \times 40-65(55)(n=6)$. Numerous small canals filled with granular content emerge from gland cells, ending beneath tegument surface (Fig. 1A). Suckers spherical, uniloculate, 30-50 (40) $(\mathrm{n}=22)$. Proliferation zone 1090-1620 $(1300) \times 65-100(90)(n=6)($ Fig. 3A-C)

Internal longitudinal musculature weakly developed, formed by small bundles of muscle fibres (Fig. 1B,C). Osmoregulatory canals situated between testes and vitelline follicles, sometimes overlapping testes and ovary. Ventral canal 5-20 (10) $(\mathrm{n}=7)$ in diameter, dorsal canal 3-5 (3) $(\mathrm{n}=7)$ (Fig. 1B,C,E,F).

Testes medullary, spherical to oval 25-65 (40 \pm 10 , $\mathrm{CV}=24 \%) \times 20-50(30 \pm 10, \mathrm{CV}=22 \%)(\mathrm{n}=30) ; 40-55$ (47) $(\mathrm{n}=9)$ in total number per mature proglottis, 18-28 (24) aporal testes, 3-10 (5) postporal testes, and 14-21 (18) preporal testes; distributed in one layer, arranged in almost one field forming two parallel rows separated by preformed uterus. Testicular field occupying 57-68\% $(62 \%)(n=9)$ of proglottis length in mature proglottides. 
A

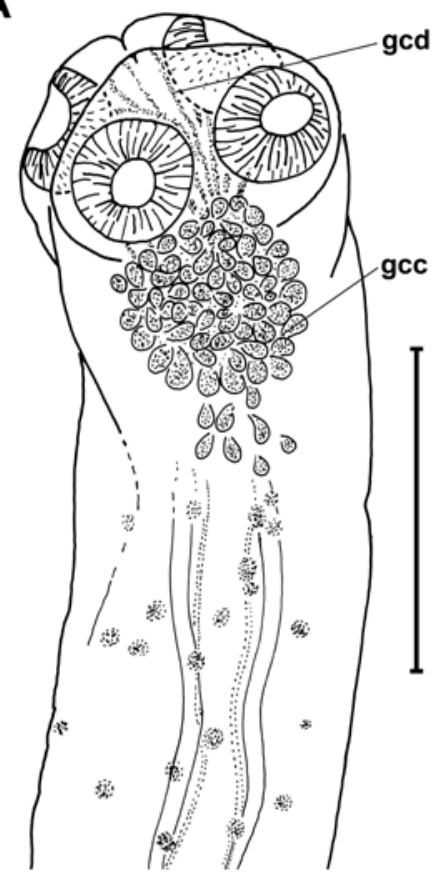

B
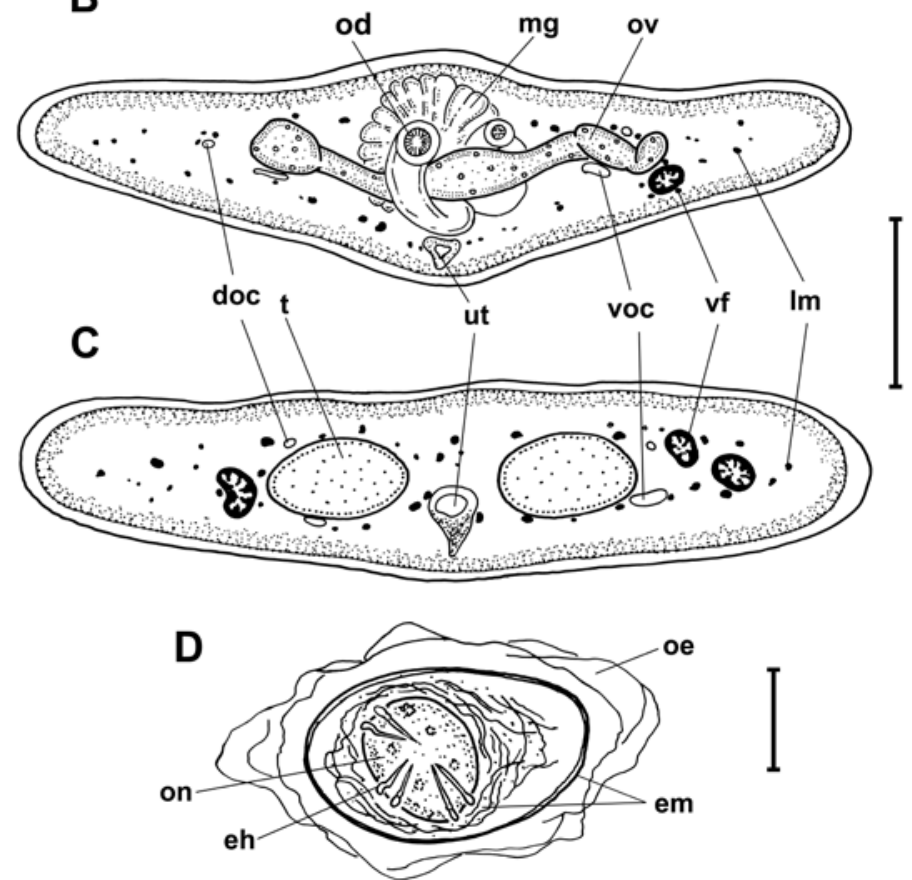

$\mathbf{F}$

$\mathbf{E}$

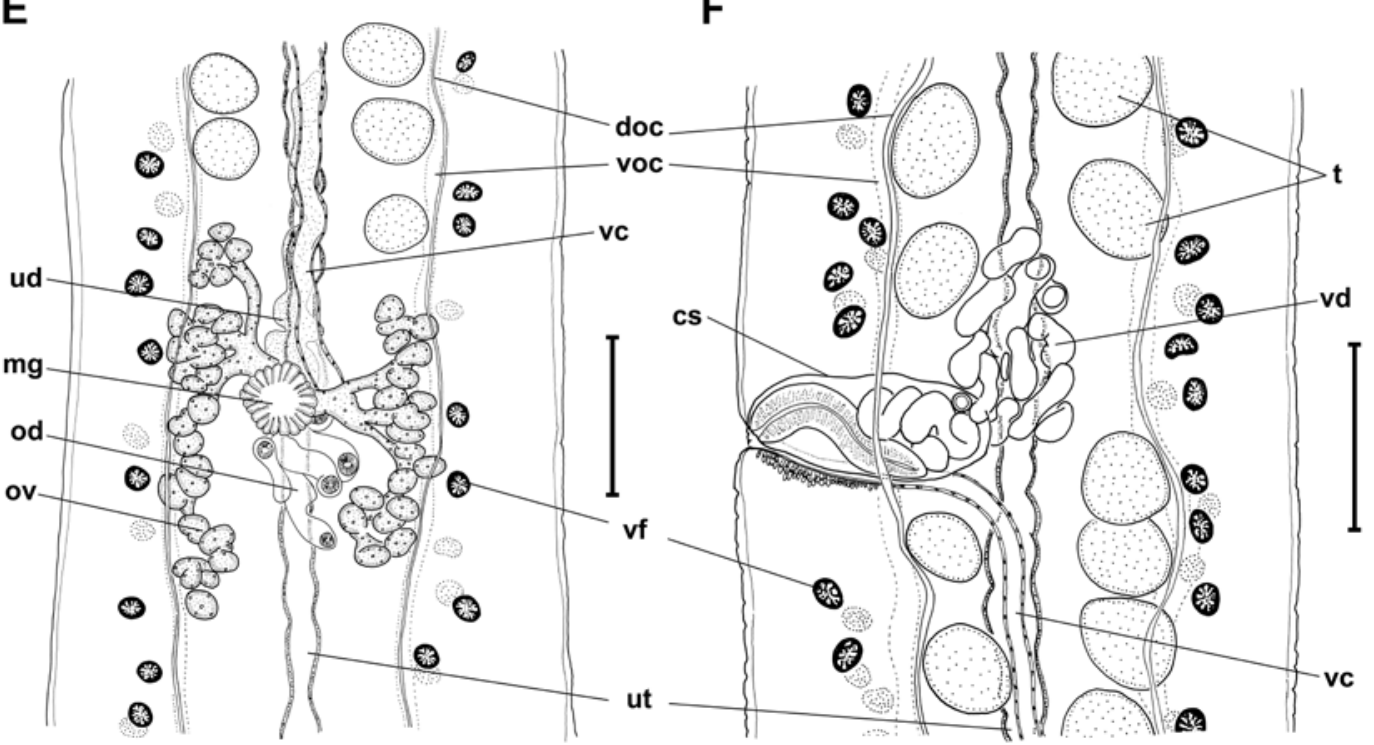

Fig. 1. Margaritaella gracilis gen. n. et sp. n. from Callichthys callichthys. A - scolex showing clustered gland cells; dorsoventral view, holotype (MACN-Pa 522/1); B - transverse section at level of the ovary, holotype (MACN-Pa 522/1); $\mathbf{C}$ - transverse section at level of testes, holotype (MACN-Pa 522/1); D - egg with collapsed outer hyaline envelope; $\mathbf{E}$ - detail of the ovary; dorsal view, paratype (IPCAS C-621/4); F - detail of terminal genitalia; dorsal view, paratype (IPCAS C-621/3). Abbreviations: cs - cirrus-sac; doc - dorsal osmoregulatory canal; eh - embryonic hooks; em - embryophore; gcc - gland cells cluster; gcd - gland cell ducts; lm longitudinal musculature; $\mathrm{mg}$ - Mehlis' gland; od - oviduct; oe - outer envelope; on - oncosphere; ov - ovary; $\mathrm{t}$ - testis; ud - uteroduct; ut - uterus; vc - vaginal canal; vd - vas deferens; vf - vitelline follicles; voc - ventral osmoregulatory canal. Scale-bars: A, E, $\mathrm{F}=100 \mu \mathrm{m} ; \mathrm{B}, \mathrm{C}=50 \mu \mathrm{m} ; \mathrm{D}=10 \mu \mathrm{m}$.

Testes not overlapping cirrus-sac, sometimes extending beyond osmoregulatory canals; never overlapping ovary (Figs. 1C,F, 2B). Cirrus-sac pyriform, with thin muscular wall, 75-130 (90) × 40-50 (45) $(\mathrm{n}=9)$, occupying 30 $40 \%(37 \%)(n=9)$ of proglottis width in mature proglottides. Cirrus long, occupying $60-80 \%(70 \%)(n=9)$ of cirrus-sac length in mature proglottides (Fig. 1F). Length of evaginated cirrus 95-145 $(\mathrm{n}=2) \times 30-35$ (Fig. 2B). Vas deferens coiled $15-25(20)(n=9)$ in diameter, directed anteriorly, surpassing body mid-line in mature and gravid proglottides. Genital pore equatorial, irregularly alternating, situated at $45-55 \%(50 \%)(n=9)$ from ante- 
A

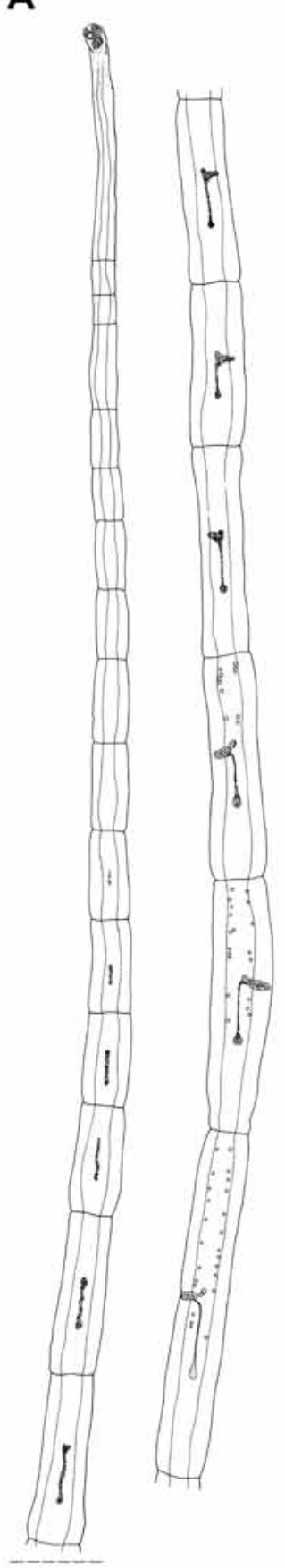

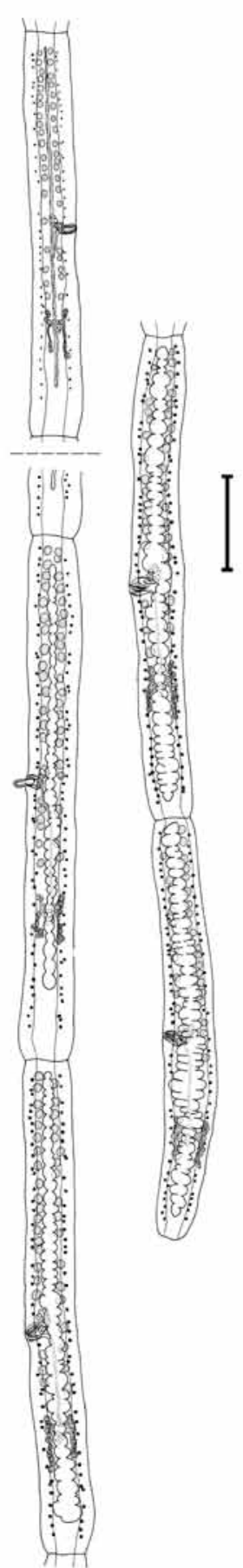

B

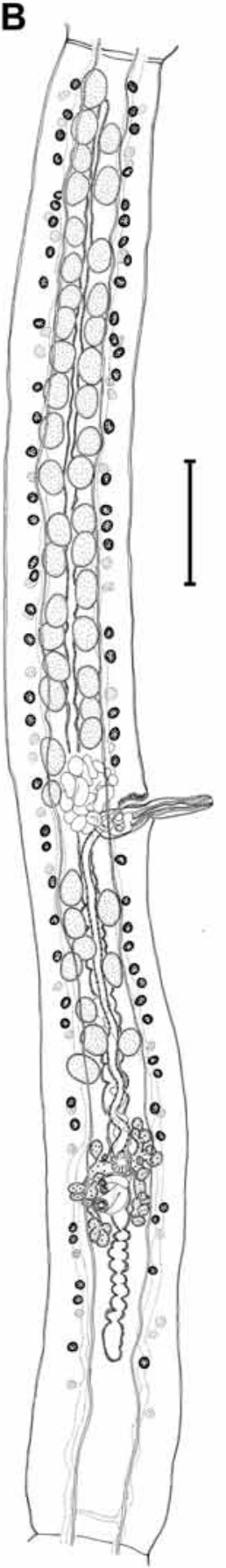

C

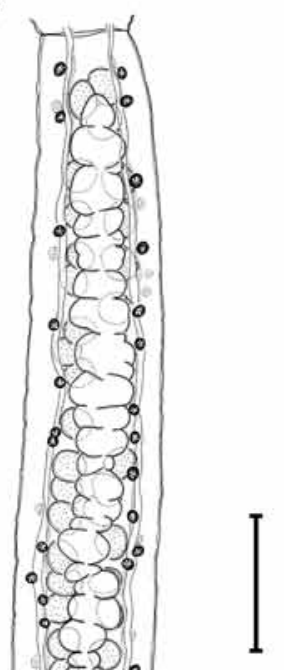

Fig. 2. Margaritaella gracilis gen. n. et sp. n. from Callichthys callichthys. A - entire worm, dash lines indicate portions of the strobila that are not shown; ventral view, holotype (MACN-Pa 522/1); B - mature proglottis; dorsal view, paratype (IPCAS C-621/1); C - gravid proglottis; ventral view, paratype (IPCAS C-621/1). Scale-bars: A $=250 \mu \mathrm{m} ; \mathrm{B}, \mathrm{C}=200 \mu \mathrm{m}$.

rior margin of proglottis in mature proglottides. Genital atrium inconspicuous (Figs. 1F, 2B).

Ovary medullary, delicate, H-shaped, with branches slender and deeply folliculate at edges, located at onethird from posterior end, 100-180 (130) $(\mathrm{n}=8)$ wide, occupying $40-70 \%(50 \%)(\mathrm{n}=8)$ of proglottis width and $0.6-1.8 \%(\mathrm{n}=3)$ of proglottis surface in mature proglottides, situated at $25-35 \%(30 \%)(n=8)$ from posterior end of mature proglottis. Mehlis' gland 25-55 (40) $\times 25$ $50(35)(\mathrm{n}=5)$ (Figs. 1B,E, 2B,C). Vagina thick-walled, $10-25(15)(\mathrm{n}=8)$ in diameter, with chromophilic cells in terminal part; vaginal sphincter not observed. Vagina anterior $(43 \%)$ or posterior $(57 \%)(n=23)$ to cirrus-sac; when vaginal canal anterior, it overlaps cirrus-sac and does not surround vas deferens (Figs. 1E,F, 2B). 

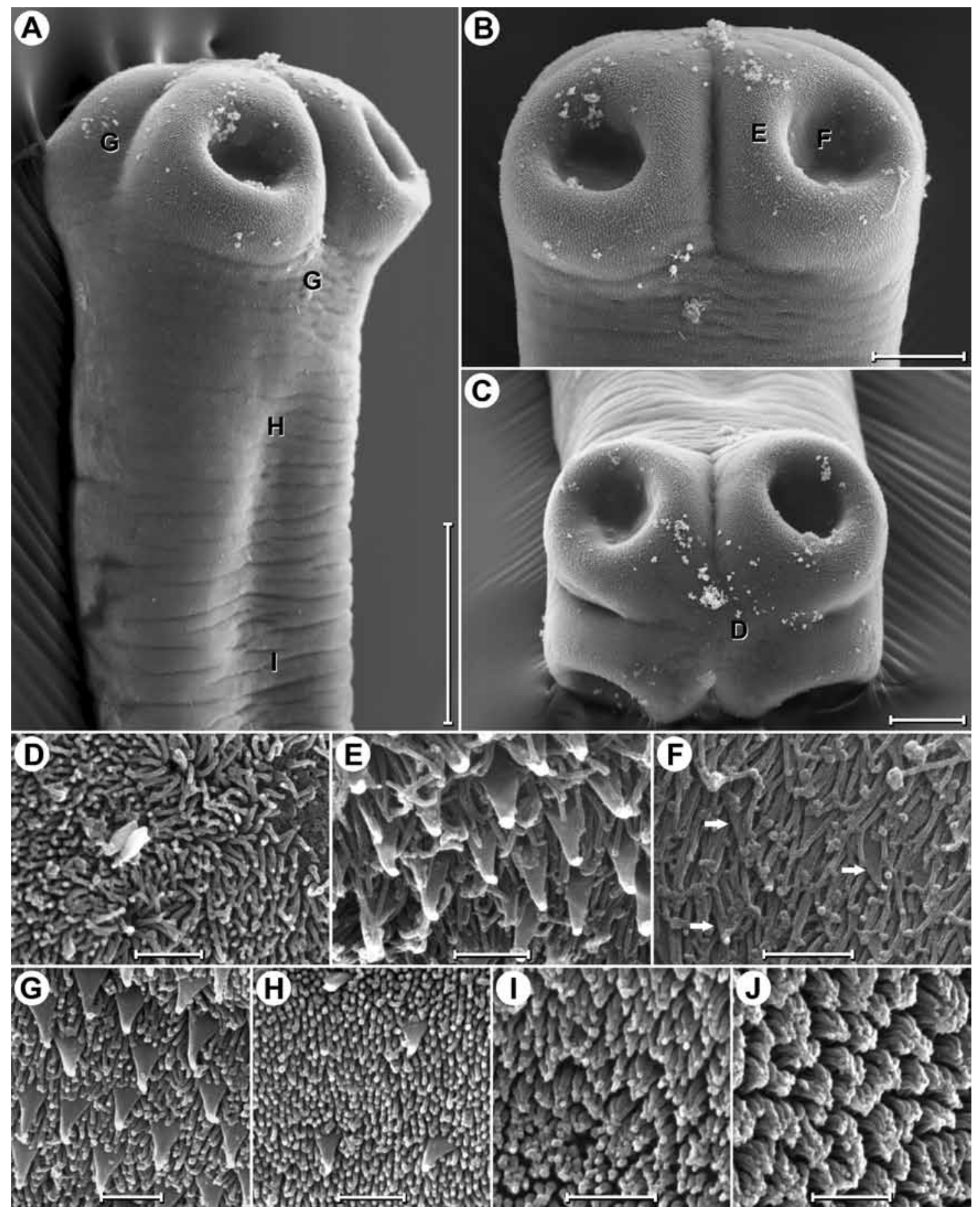

Fig. 3. Margaritaella gracilis gen. n. et sp. n. from Callichthys callichthys, scanning electron micrographs. A - scolex showing proliferation zone, sublateral view; B - scolex showing spherical suckers, dorsoventral view; $\mathbf{C}$ - scolex showing four lobes, apical view; letters D-J indicate surfaces shown at higher magnification in Fig. 3D-J; D - apical surface of the scolex; E - marginal surface of suckers; $\mathbf{F}$ - luminal surface of suckers; $\mathbf{G}$ - non-adherent surface of suckers and anterior surface of proliferation zone; note the same type and distribution of microtriches; $\mathbf{H}$ - mid-surface of proliferation zone; $\mathbf{I}$ - posterior surface of proliferation zone; $\mathbf{J}$ - surface of an immature proglottis. Scale bars: $\mathrm{A}=50 \mu \mathrm{m} ; \mathrm{B}, \mathrm{C}=20 \mu \mathrm{m} ; \mathrm{D}-\mathrm{J}=1 \mu \mathrm{m}$.

Vitelline follicles medullary, scarce, with few follicles in paramuscular position in transverse section; arranged in two narrow lateral bands occupying about $90 \%$ of total proglottis length, not reaching posterior margin of proglottis, largely surpassing ovary. Follicles interrupt- ed at level of cirrus-sac, rarely overlapping testes (Figs. 1B, C, 2B,C).

Uterine stem medullary but frequently partly cortical. Uterine development of type 1 (sensu de Chambrier et al. 2004). Uterus preformed in mature proglottides, largely 
surpassing ovary posteriorly. Uterus occupying 20-80\% $(50 \%)(\mathrm{n}=12)$ of proglottis width and $80-95 \%(90 \%)$ $(\mathrm{n}=12)$ of proglottis length; with 35-60 (45) poral branches and 35-60 (50) $(\mathrm{n}=9)$ aporal branches. Uteroduct 95-225 (165) × 15-25 (20) $(\mathrm{n}=3)$ wide, occupies $5-10 \%(8 \%)(n=3)$ of proglottis length (Figs. 1B,C,E, 2B,C).

Intrauterine eggs elliptical, with collapsed outer envelope; embryophore thick, 27-31 (29) × 17-23 (19) $(\mathrm{n}=4)$ consisting of two layers (outer transparent, inner containing nuclei), oncosphere 12-15 (12) × 9-11 (10) $(\mathrm{n}=4)$, with hooks 4-6 (5) $(\mathrm{n}=3)$ long (Fig. 1D).

Ty pe host: Callichthys callichthys (Linnaeus, 1758) (Siluriformes: Callichthyidae). Vernacular name in Argentina "cascarudo".

Type locality: Paraná-Guazú river (tributary of Paraná River) ( $\left.33^{\circ} 54^{\prime} \mathrm{S}, 58^{\circ} 52^{\prime} \mathrm{W}\right)$, Entre Rios Province, Argentina.

Type material: Holotype MANC-Pa No. 522/1 (entire worm and transverse sections, on one slide), paratypes MANC-Pa 522/2 (entire worm and transverse sections, on one slide), MANC-Pa 522/3A-B (entire worm and transverse sections, on two slides), MANC-Pa 522/4-8 (three scolices, pieces of strobila and transverse sections, on five slides) and paratypes IPCAS C-621/1 (entire worm and transverse sections, on one slide), IPCAS C-621/2 (scolex and piece of strobila with immature proglottides, on one slide), IPCAS C-621/3 (piece of strobila with mature proglottides and transverse sections, on one slide), IPCAS C-621/4 (piece of strobila with gravid proglottides and transverse sections, on one slide).

Site: intestine.

In fection rate: Prevalence: $50 \%(1 / 2)$; intensity 12 worms per host.

Etymology: From the Latin "gracilis" meaning "gracile", feminine in gender.

\section{Microthrix pattern}

SEM observation of the tegument surface revealed the presence of acicular, capilliform and gladiate microtriches distributed on the scolex, proliferation zone and immature proglottides. The microtriches of each type have fairly similar sizes: acicular filitriches $0.25-0.50(0.40) \times$ $0.10-0.15(0.10)(\mathrm{n}=25)$; capiliform filitriches $0.60-1.0$ $(0.80) \times 0.05-0.10(0.08)(\mathrm{n}=22)$; and gladiate spinitriches $0.60-1.20(0.80) \times 0.20-0.60(0.40)(n=20)$.

Microtriches on the scolex are distributed as follows: only acicular filitriches on the apical surface of the scolex (Fig. 3D); sparse gladiate spinitriches interspersed with capilliform filitriches on the luminal surface of suckers (Fig. 3F); dense gladiate spinitriches interspersed with capilliform filitriches on the marginal ring surface of suckers (Fig. 3E); gladiate spinitriches interspersed with acicular filitriches on the non-adherent surface of suckers (Fig. 3G). The proliferation zone is covered with gladiate spinitriches interspersed with acicular filitriches on its anterior surface (Fig. 3G), very sparse gladiate spinitriches (decreasing in density posteriorly) interspersed with acicular filitriches on its mid-surface (transitional surface) (Fig. 3H), and only acicular filitriches on its posterior surface (Fig. 3I). Immature proglottides only have densely packed acicular filitriches (Fig. 3J). The central apical surface of the scolex is covered with scarce tumuli exhibiting a pinched-off appearance, probably due to the released content from the cluster of gland cells.

\section{DISCUSSION}

Margaritaella gracilis gen. $\mathrm{n}$. et sp. $\mathrm{n}$. belongs to the Proteocephalinae as defined by Schmidt (1986) and Rego (1994), based on the following characters: medullary position of testes, ovary, uterus and vitelline follicles. The new species is allocated to a new genus because it possesses a scolex with four spherical uniloculate suckers, a conspicuous cluster of drop-shaped gland cells posterior to the suckers; all proglottides much longer than wide; testes almost arranged in one field (composed of two parallel rows of testes not overlapping ovary); an H-shaped ovary located at one-third from the posterior end of the proglottis; vitelline follicles arranged in two narrow lateral bands, which do not reach the posterior margin of the proglottis but extend far beyond the ovary; and a uterus largely surpassing the ovary posteriorly (Fig. 2A-C). The fact that some of these characters are rare in Proteocephalidea makes $M$. gracilis a particularly interesting fish parasite.

Notwithstanding the unique morphology of $M$. gracilis, it shares some characters with other proteocephalidean cestodes from different fish hosts. For example, the scolices of Proteocephalus cernuae (Gmelin, 1790), $P$. longicollis (Zeder, 1800) and P. soniae de Chambrier et Vaucher, 1994 also have a cluster of gland cells located posterior to the suckers (see de Chambrier and Vaucher 1994, Scholz et al. 1998, Scholz and Hanzelová 1998). However, $P$. cernuae and $P$. longicollis possess a fifth sucker at the apex of the scolex, and $P$. soniae has an apical organ, whereas in $M$. gracilis they are absent.

Vaucheriella bicheti de Chambrier, 1987 and Ophiotaenia habanensis Freze et Ryšavý, 1976, both from reptiles, are similar to $M$. gracilis in the morphology of the proglottides (all much longer than wide) and the arrangement of testes (in one field distributed in two parallel rows separated by the uterus) (see fig. 5 of Freze and Ryšavý 1976, and fig. 1A and B of de Chambrier 1987). Margaritaella gracilis differs from $V$. bicheti because the latter, as a member of the Zygobothriinae, has cortical vitelline follicles located ventrally between the genital pore and the ovary, and a small and bilobed ovary. On the other hand, $O$. habanensis has a compact and bilobed ovary located near the posterior end of the proglottis, and both the vitelline follicles and uterus do not extend posteriorly to the ovary.

Recently, Ammann and de Chambrier (2008) and de Chambrier et al. (2012) proposed the relative ovarian size as a useful character to distinguish between two 
similar genera, namely Proteocephalus Weinland, 1858, parasites of teleost fishes, and Ophiotaenia La Rue, 1911, parasites of reptiles. It is interesting to note that the ovary of M. gracilis, a parasite of Neotropical fishes, is smaller (0.6-1.8\%) than those of Proteocephalus species found in fishes from all over the world (5.4-28.8\%) (Table 2 in de Chambrier et al. 2012) and those of Ophiotaenia species occurring in reptiles from the New World (1.95.5\%) (Table 2 in Ammann and de Chambrier 2008). In addition, the relative size of the ovary of the Neotropical proteocephalidean Tejidotaenia appendiculata (Baylis, 1947) from South American lizards (8.4\% according to Fig. 5 of Rego and de Chambrier 2000), is similar to that of the Neotropical genus Proteocephalus, the members of which parasitize fishes (6.1-18.2\%, sensu de Chambrier et al. 2012). In turn, the ovaries of T. appendiculata and M. gracilis show a similar location (28-30\% and $25-35 \%$, respectively).

In most of the known proteocephalideans, the uterus usually does not extend beyond or slightly overlaps the ovary, except for a few species in which the uterus occupies almost the entire length of gravid proglottides, such as Cairaella henrii Coquille et de Chambrier, 2008, Cangatiella arandasi Pavanelli et Machado dos Santos, 1991, C. macdonaghi (Szidat et Nani, 1951), Proteocephalus sophiae de Chambrier et Rego, 1994, Pseudocrepidobothrium eirasi (Rego et de Chambrier, 1995), and T. appendiculata (see de Chambrier and Rego 1994, Rego and de Chambrier 1995, 2000, Gil del Pertierra and Viozzi 1999, Coquille and de Chambrier 2008). In contrast, the uterus of $M$. gracilis extends largely posterior to the ovary in mature (preformed uterus) and gravid proglottides, but it does not not reach the end of the proglottis.

On the apical surface of the scolex, capilliform filitriches are the most common microthrix type, this type being the only one found in, for example, Lenhataenia megacephala (Woodland, 1934); Monticellia lenha Woodland, 1933; M. magna (Rego, dos Santos et Silva, 1974); Nomimoscolex chubbi (Pavanelli et Takemoto, 1995); N. sudobim Woodland, 1935; Proteocephalus hemioliopteri de Chambrier et Vaucher, 1997; P. sulcatus (Klaptocz, 1906); Spatulifer maringaensis Pavanelli et Rego, 1989 and S. rugosa (Woodland, 1935) (see Gil de Pertierra 2004, 2005, de Chambrier et al. 2005, 2006b, 2007, de Chambrier and Scholz 2008, Arredondo and Gil de Pertierra 2008). In contrast, acicular filitriches are the only type present on the apical surface of the scolex in M. gracilis (present paper), Monticellia belavistensis
Pavanelli, Machado, Takemoto et dos Santos, 1994 and M. ventrei de Chambrier et Vaucher, 1999 (see sizes of microtriches in Gil de Pertierra 2005). On the proliferation zone, gladiate spinitriches are the most common microthrix type and it is the only one present in $M$. ventrei, N. chubbi, N. lopesi Rego, 1989 and Scholzia emarginata (Diesing, 1850) (see de Chambrier et al. 2005, Gil de Pertierra 2005), whereas two types of microtriches are found on the proliferation zone of M. gracilis (gladiate spinitriches and acicular filitriches, see above for microthrix distribution) and M. belavistensis (gladiate spinitriches and capilliform filitriches, see Gil de Pertierra 2005).

However, in some of these species, the microtriches were reported but their measurements were not provided (e.g., L. megacephala, M. lenha, N. sudobim and P. sulcatus), despite the relevance of size for their correct classification (Chervy 2009). This fact indicates the need to confirm the actual identity of the microthrix types found in some previously described species, as well as to provide a more complete set of data for new species descriptions. Another important issue for a more accurate taxonomic classification of proteocephalideans is to describe the microtriches present on all the tegumental surfaces, which may show specific differences (e.g., apex of the scolex, luminal and marginal surface of suckers, non-adherent surface, metascolex surface, when present, proliferation zone, proglottides) (see Gil de Pertierra 2005).

Margaritaella gracilis is the first proteocephalidean to be described from Callichthys callichthys, a small fish usually used to keep the aquarium clean or as bait for large siluriforms (Almirón et al. 2008, Froese and Pauly 2012). Pimelodids of commercial value are the most frequently reported freshwater fish hosts of proteocephalideans in South America (de Chambrier and Vaucher 1999, Rego et al. 1999, de Chambrier et al. 2006a). However, new parasite species are continually being found in fishes of other orders or families. For example, Nomimoscolex chubbi, N. dechambrieri Gil de Pertierra 2003 and N. guillermoi Gil de Pertierra, 2003 are parasites of Gymnotus carapo, usually used as bait fish like $C$. callichthys (see Pavanelli and Takemoto 1995, Gil de Pertierra 2003). This reflects the importance of studying fishes of minor commercial value for discovering new proteocephalidean cestodes.

Acknowledgements. Special thanks are due to the two reviewers for their valuable comments that helped improve this manuscript. Research was supported by Universidad de Buenos Aires (Grants UBACYT - 20020090200511 and 20020090200529).

\section{REFERENCES}

Arredondo N.J., Gil de Pertierra A.A. 2008: The taxonomic status of Spatulifer cf. maringaensis Pavanelli \& Rego, 1989 (Eucestoda: Proteocephalidea) from Sorubim lima (Bloch \& Schneider) (Pisces: Siluriformes), and the use of the microthrix pattern in the discrimination of Spatulifer spp. Syst. Parasitol. 70: 223-236.

Almirón A., Casciotta J., Ciotek L., Giorgis P. 2008: Guía de los Peces del Parque Nacional Pre-Delta. Administración 
de Parques Nacionales, Ciudad Autónoma de Buenos Aires, $216 \mathrm{pp}$.

Ammann M., De Chambrier A. 2008: Ophiotaenia gilberti sp. $\mathrm{n}$. (Eucestoda: Proteocephalidea), a parasite of Thamnodynastes pallidus (Serpentes: Colubridae) from Paraguay. Rev. Suisse Zool. 115: 541-551.

De Chambrier A. 1987: Vaucheriella bicheti n. gen., n. sp. (Cestoda: Monticelliidae, Zygobothriinae) parasite of Tropidophis cf. taczanowskyi (Steindachner, 1880) (Serpentes: Tropidophidae) des Andes équatoriennes. Rev. Suisse Zool. 94: 829-840.

De Chambrier A., Binh T.T., Scholz T. 2012: Ophiotaenia bungari n. sp. (Cestoda), a parasite of Bungarus fasciatus (Schneider) (Ophidia: Elapidae) from Vietnam, with comments on relative ovarian size as a new and potentially useful diagnostic character for proteocephalidean tapeworms. Syst. Parasitol. 81: $39-50$

de Chambrier A., Rego A.A. 1994: Proteocephalus sophiae n. sp. (Cestoda: Proteocephalidae), a parasite of the siluroid fish Paulicea luetkeni (Pisces: Pimelodidae) from the Brazilian Amazon. Rev. Suisse Zool. 101: 361-368.

de Chambrier A., Rego A.A., Gil de Pertierra A.A. 2005: Redescription of two cestodes (Eucestoda: Proteocephalidea), parasitic in Phractocephalus hemiliopterus (Siluriformes) from the Amazon and erection of Scholzia gen. n. Rev. Suisse Zool. 112: 735-752.

De Chambrier A., Scholz T. 2008: Tapeworms (Cestoda: Proteocephalidea) of firewood catfish Sorubimichthys planiceps (Siluriformes: Pimelodidae) from the Amazon River. Folia Parasitol. 55: 17-28.

de Chambrier A., Scholz T., Beletew M., Mahmoud Z.N. 2007: Redescription of Proteocephalus sulcatus (Klaptocz, 1906) (Cestoda: Proteocephalidea), a poorly known parasite of Clarotes laticeps (Pisces: Siluriformes) in the Sudan. Rev. Suisse Zool. 114: 693-702.

de Chambrier A., Scholz T., Kuchta R., Posel P., Mortenthaler M., Chuquipiondo Guardia C. 2006a: Tapeworms (Cestoda: Proteocephalidea) of fishes from the Amazon River in Peru. Comp. Parasitol. 73: 111-120.

de Chambrier A., Takemoto R.M., Pavanelli G.C. 2006b: Nomimoscolex pertierrae n. sp. (Eucestoda: Proteocephalidea), a parasite of Pseudoplatystoma corruscans (Siluriformes: Pimelodidae) in Brazil and redescription of N. sudobim Woodland, 1935, a parasite of $P$. fasciatum. Syst. Parasitol. 64: 191-202.

de Chambrier A., Vaucher C. 1994: Etude morpho-anatomique et génétique de deux nouveaux Proteocephalus Weinland, 1858 (Cestoda: Proteocephalidae) parasites de Platydoras costatus (L.), poisson siluriforme du Paraguay. Syst. Parasitol. 27: 173-185.

de Chambrier A., Vaucher C. 1999: Proteocephalidae et Monticelliidae (Eucestoda: Proteocephalidea) parasites de poissons d'eau douce au Paraguay, avec descriptions d'un genre nouveau et de dix espèces nouvelles. Rev. Suisse Zool. 106: 165-240.

de Chambrier A., Zehnder M.P., Vaucher C., Mariaux J. 2004: The evolution of the Proteocephalidea (Platyhelminthes, Eucestoda) based on an enlarged molecular phylogeny, with comments on their uterine development. Syst. Parasitol. 59: $159-171$.

Chervy L. 2009: Unified terminology for cestode microtriches: a proposal from the International Workshops on Cestode Systematics in 2002-2008. Folia Parasitol. 56: 199-230.
Coquille S.C., De Chambrier A. 2008: Cairaella henrii gen. n., sp. n., a parasite of Norops trachyderma (Polychrotidae), and Ophiotaenia nicoleae sp. n. (Eucestoda: Proteocephalidea), a parasite of Thecadactylus rapicauda (Gekkonidae), in Ecuador. Folia Parasitol. 55: 197-206.

FrEZE V.I., RYŠAVÝ B. 1976: Cestodes of the suborder Proteocephalata Spassky, 1957 (Cestoda - Pseudophyllidea) from Cuba and description of a new species Ophiotaenia habanensis sp. n. Folia Parasitol. 23: 97-104.

Froese R., Pauly D. (Eds.) 2012: FishBase. World Wide Web electronic publication. www.fishbase.org, version 02/2012.

Gil de Pertierra A.A. 2003: Two new species of Nomimoscolex (Cestoda: Proteocephalidea, Monticelliidae) from Gymnotus carapo (Pisces: Gymnotiformes) in Argentina. Mem. Inst. Oswaldo Cruz 98: 345-351.

Gil de Pertierra A.A. 2004: Redescription of Monticellia magna Rego, dos Santos et Silva, 1974) (Eucestoda: Monticelliidae) parasite of Pimelodus spp. (Pisces: Siluriformes) from Argentina, and morphological study of microtriches. Rev. Suisse Zool. 111: $11-20$

Gil de Pertierra A.A. 2005: Comparative study of the microtriches of adult cestodes (Proteocephalidea: Monticelliidae), and some comments on their systematic value. Zool. Anz. 243: 295-304.

Gil de Pertierra A.A., Viozzi G.P. 1999: Redescription of Cangatiella macdonaghi (Szidat y Nani, 1951) comb. nov. (Cestoda: Proteocephalidae) a parasite of the atheriniform fish Odontesthes hatcheri (Eigenmann, 1909) from the Patagonian region of Argentina. Neotrópica 45: 13-20.

Langeron M. 1949: Précis de Microscopie. 7th Ed. Masson \& Cie, Paris, 1429 pp.

Pavanelli G.C., Takemoto R.M. 1995: New species of Proteocephalus (Cestoda: Proteocephalidae) parasitic in fishes from the Paraná River, Paraná River, Paraná, Brazil. Mem. Inst. Oswaldo Cruz 90: 593-596.

Rego A.A. 1994: Order Proteocephalidea Mola, 1928. In: L.F. Khalil, A. Jones and R.A. Bray (Eds.), Keys to the Cestode Parasites of Vertebrates. CAB International, Wallingford, pp. 257-293.

Rego A.A., de Chambrier A. 1995: Crepidobothrium eirasi n. sp. (Cestoda: Proteocephalidae), a parasite of the siluroid fish Phractocephalus hemiliopterus (Schneider, 1801) (Pisces: Pimelodidae) from the Brazilian Amazon. Rev. Suisse Zool. 102: 3-11.

Rego A.A., de Chambrier A. 2000: Redescription of Tejidotaenia appendiculata (Baylis, 1947) (Cestoda: Proteocephalidea), a parasite of Tupinambis teguixin (Sauria: Teiidae) from South America. Mem. Inst. Oswaldo Cruz 95: 161-165.

Rego A.A., Chubb J.C., Pavanelli G.C. 1999: Cestodes in South American freshwater teleost fishes: keys to genera and brief description of species. Rev. Brasil. Zool. 16: 299-367.

Schmidt G.D. 1986: CRC Handbook of Tapeworm Identification. CRC Press, Boca Raton, Florida, 675 pp.

Scholz T., Drábek R., Hanzelová V. 1998: Scolex morphology of Proteocephalus tapeworms (Cestoda: Proteocephalidae), parasites of freshwater fish in the Palaearctic Region. Folia Parasitol. 45: 27-43.

Scholz T., Hanzeloví V. 1998: Tapeworms of the genus Proteocephalus Weinland, 1858 (Cestoda: Proteocephalidae), parasites of fishes in Europe. Studie AV ČR, No. 2/98. Academia, Praha, Czech Republic, 119 pp. 